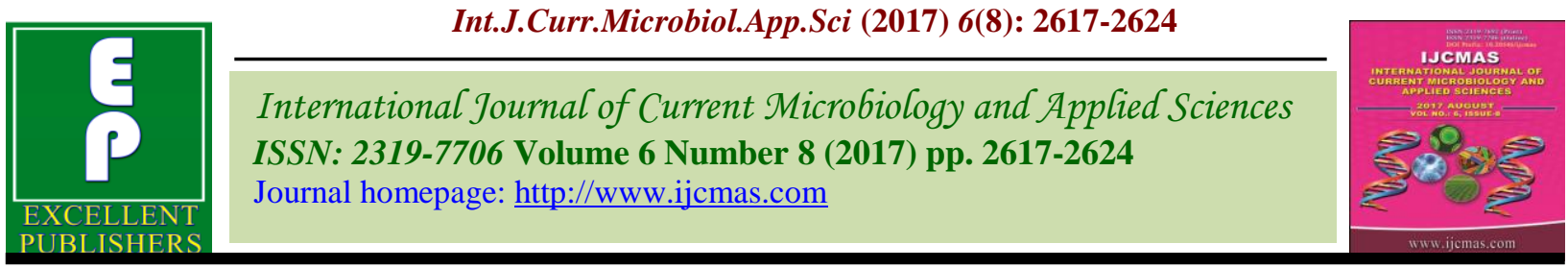

Original Research Article

https://doi.org/10.20546/ijcmas.2017.608.311

\title{
An Efficient Method for In Vitro Propagation of Gisela 5 (Prunus cerasus X Prunus canescens) - Clonal Cherry Rootstock
}

\author{
Vishal Sharma*, Manisha Thakur and Akhil Kumar \\ Department of Biotechnology, Dr Yashwant Singh Parmar University of Horticulture and \\ Forestry Nauni, Solan (HP), 173230, India \\ *Corresponding author
}

\section{A B S T R A C T}

A study was carried out to establish efficient and reliable in vitro propagation protocol for Gisela 5 (Prunus cerasus x Prunus canescens) - clonal cherry rootstock. Axillary and

Keywords

In vitro, Clonal

cherry rootstock, Glasshouse.

Article Info

Accepted:

21 June 2017

Available Online:

10 August 2017 terminal buds of 'Gisela 5' were collected in the spring and cultured on MS medium. After the in vitro cultures were sufficiently established, experiments were conducted to assess the influence of different levels of benzyladenine (BA), kinetin (Kin), thidiazuron (TDZ), gibrellic acid $\left(\mathrm{GA}_{3}\right)$ and indole-3-butyric acid (IBA) on in vitro shoot multiplication. Data was collected on multiplication rate, shoot number, shoot length, per cent rooting, root number and root length after an interval of six weeks. Shoot multiplication and shoot length showed an increase with the increase in number of passages of subculturing which increased to a maximal of $1: 10$ and $6.5 \mathrm{~cm}$ after fourth passage. Maximum in vitro rooting (100\%) was achieved on full strength MS medium fortified with $0.5 \mathrm{mg} / \mathrm{l} \mathrm{IBA}$ whereas, very less rooting was achieved on full strength solid MS medium fortified with IAA and NAA. The Highest number of roots and root length observed on full strength solid MS medium supplemented with $0.5 \mathrm{mg} / \mathrm{l} \mathrm{IBA}$ followed by $1.0 \mathrm{mg} / \mathrm{l} \mathrm{NAA}$ and $0.5 \mathrm{mg} / \mathrm{l} \mathrm{IAA}$. Rooted plantlets were transplanted in sterilized sand for hardening and kept in the glasshouse, where 90 per cent survival was observed after 4 weeks of transfer.

\section{Introduction}

Cherry fruits have been a favourite human food for centuries. From among the fruits of the temperate climate, they excel all others in ripening and tempting colour. The fruits are attractive in appearance, on account of their bright, shiny skin colour and their subtle flavour and sweetness is of great appeal to most fruit consumers of the world. Cherries are usually grown in the coldest climates at an altitude of about 1,600 to $2,700 \mathrm{~m}$ above the mean sea level requiring $1,000-1,500$ hours of chilling period during winters. Almost all commercial Prunus fruit trees are either budded or grafted on recommended rootstocks. Prunus rootstocks are commercially produced through stem seeds or cuttings. The production of rootstocks through seeds result in segregation and therefore uniform plants cannot be obtained and the mother plant characteristics cannot be maintained. Alternatively, rootstocks can be produced by cuttings and this clonal propagation method is favoured in many parts of the world, because it allows the production of uniform propagules. However, propagation by cuttings is difficult in some Prunus genotypes due to the low rooting potential (Fachinello, 2000) and propagation by cutting 
does not guarantee healthy and disease-free plants (Holtz et al., 1995). In these circumstances, in vitro propagation of rootstocks emerge as a viable alternative way of propagation because it is not dependent on season, provides clean, disease and virus-free planting material. Prunus avium L. is especially difficult to root both in vitro and in vivo.

Like majority of fruit crops cherry trees are also propagated by grafting the scion wood on rootstock. Seedling rootstocks are not uniform and show great variability in tree vigour and bearing age. These difficulties can be overcome by the use of dwarfing clonal rootstocks. Gisela 5 is a very important dwarfing cherry rootstock for sweet cherry, developed from the cross between Prunus cerasus and Prunus canescens. It is considered as very useful and economically important dwarfing rootstocks for intensive sweet cherry growing in temperate conditions. There are very few data about micropropagation of Gisela 5 in the scientific literature (Sisko, 2011).

The aim of the present research was to develop an effective protocol for in vitro multiplication and rooting of Gisela 5 rootstock by using different concentrations and combinations of growth regulators.

\section{Materials and Methods}

\section{Plant material}

Experimental plants of Gisela 5 were selected from well-established nursery maintained at PCDO (Progeny cum demonstration orchard) Bajaura, Kullu (HP). Shoot cuttings were procured from the selected mother plants in the month of October, 2014 to September, 2015 and kept in glass jars containing tap water to prevent wilting until they were processed in the laboratory. Leaves were removed from shoot cuttings taking care not to damage the axillary and terminal buds.

\section{Surface sterilization and inoculation of explants}

Shoot apices and axillary buds excised from the selected tree were used as explants for in vitro propagation. Fifty explants were collected every month from January to December for culture establishment. Explants were prepared by cutting sprouting shoot buds with the help of sharp blade and collecting in a beaker containing water and then washing under running tap water with 2-3 drops of teepol for 30 minutes. The explants were then treated with carbendazime (Bavistine, BASF, India) for 30 minutes followed by streptocycline $(0.1 \%)$ for one minute. Explants were treated with $1 \%$ solution of sodium hypochlorite for 15 minutes and finally washed 3 to 4 times with autoclaved distilled water to remove all the traces of sterilants under aseptic conditions.

The sterilized explants were transferred to $100 \mathrm{ml}$ Erlenmeyer flasks containing $20 \mathrm{ml}$ MS (Murashige and Skoog, 1962) basal medium supplemented with different concentrations and combinations of BA, Kin, TDZ and $\mathrm{GA}_{3}$ for the establishment of shoot buds. The $\mathrm{pH}$ of the medium was adjusted at 5.8 with the help of $1 \mathrm{~N} \mathrm{HCl}$ and/or $\mathrm{NaOH}$ before gelling with $0.8 \%$ agar [(w/v); SigmaAldrich] and then autoclaved for $20 \mathrm{~min}$ at 1.1 $\mathrm{kg} \mathrm{cm}^{-2}$ pressure.

\section{Culture conditions}

The cultures were incubated at $25 \pm 2{ }^{\circ} \mathrm{C}$ under 16 hour photoperiod at a light intensity of 50-60 $\mu \mathrm{mol} \mathrm{m}^{-1} \mathrm{~s}^{-1}$ provided by $40 \mathrm{~W}$ cool white fluorescent lamps (Philips, Bangalore, India). Per cent bud establishment was recorded after four weeks of culture. 


\section{Multiplication}

Healthy developed shoots were transferred on to different shoot multiplication medium containing different concentration of growth regulators (BA, Kin, TDZ, $\mathrm{GA}_{3}$ and IBA). The multiplication medium which showed healthy, long and good quality microshoots after 3-4 weeks of culture was selected for further multiplication. Subculturing was performed after every 3-4 weeks by transferring microshoots to fresh multiplication medium.

\section{Rooting}

For rooting, in vitro developed shoots (1.5-3 $\mathrm{cm}$ long) of Gisela 5 were placed on full strength and half strength MS medium containing different concentrations of IBA, NAA and IAA. In all rooting experiments $4 \mathrm{~g} / \mathrm{l}$ agar was used for solidification.

\section{Hardening and acclimatization}

For hardening and acclimatization, in vitro regenerated plants were removed from culture tubes and washed under running tap water for 1 hour to remove agar sticking to the roots. Thereafter, the plants were kept dipped in $1 \%$ solution of carbendezim for 30 minutes before transferring to plastic pots containing sterilized sand. The pots were covered with glass jars and kept in glass house at $25^{\circ} \mathrm{C}$ temperature. Jars were removed after 15 days and survival rate of plantlets were recorded after one month of transfer to in vivo conditions.

\section{Statistical analysis}

The experiments were repeated three times with similar trend of results using completely randomized design (Gomez and Gomez, 1984). The significance of treatment effects on various parameters was determined using analysis of variance (ANOVA). If the treatments were found to be significant, then their comparative performance was tested after obtaining the critical difference $\left(\mathrm{CD}_{0.05}\right)$.

\section{Results and Discussion}

\section{In vitro shoot multiplication}

The axillary and terminal buds of Gisela 5 resulted in 66.70 per cent uncontaminated cultures after four weeks of incubation following the previously standardized protocol for surface sterilization (Thakur et al., 2016). Surface sterilization of explants is necessary to make them free from contaminants (Beura et al., 2003). The cultured buds showed 75.00 per cent proliferation after 3 weeks of culture on MS medium supplemented with $0.5 \mathrm{BA}$ and 0.5 $\mathrm{GA}_{3}$ (Table 1). The proliferated shoots of Gisela 5 were then cut into small pieces with 2-4 nodal segments and cultured onto MS medium with different concentration and combination of growth regulators for multiplication. It was observed that shoot multiplication, length of shoots and leaf size varied with the concentration and type of plant growth regulators used. Shoot multiplication was observed in all the growth regulator combinations tried in the medium (Table 2). Highest multiplication rate of 1:6 was observed in the MS medium fortified with $0.5 \mathrm{mg} / \mathrm{l} \mathrm{BA}, 0.5 \mathrm{mg} / \mathrm{l} \mathrm{GA}_{3}$ and $0.1 \mathrm{mg} / \mathrm{l}$ IBA (Figure 1). In most of the growth regulator combinations, maximum of $1: 5$ multiplication rate was observed with elongated shoots and bigger leaf size. The addition of phytohormones was crucial for multiple shoot formation but no significant difference in multiplication rates was found among medium supplemented with $\mathrm{BA}, \mathrm{GA}_{3}$ and IBA.

The continuous presence of cytokinin in the nutrient medium is of utmost importance for 
the formation of new shoots (Nordstrom and Eliasson, 1986). Therefore, in the presence of BA, abundant shoot proliferation occurred. The function of continuous availability of BA during shoot multiplication is to break the apical dominance, stimulate growth of new shoots, and complete or partial inhibition of root formation (Muna et al., 1999). Similar to our findings, Buyukdemirci (2008), Filiz (2010) and Sisko (2011) reported best shoot multiplication on medium fortified with BA, $\mathrm{GA}_{3}$ and IBA in Gisela 5.

\section{Effect of sub culturing on in vitro shoot multiplication}

Shoot multiplication rate and length of shoots showed an increase with the increase in number of sub culturings which increased to a maximal of $1: 10$ and $6.5 \mathrm{~cm}$ after fourth passage, as evident from table 3 . The effect of subculturing was also observed on per cent rooting which showed an increasing trend from 0 per cent after first subculture to 65 per cent after fourth subculture.

The ability to produce roots and shoots in apple rootstock M9 and cherry rootstock F12/1 was dependent on the total time spent in culture (Grant and Hammatt, 1999). Marjanovic et al., (2000) obtained three fold multiplication after third multiplication cycle during micro-propagation of wild cherry.

Fig.1 In vitro shoot multiplication in Gisela 5 on MS medium supplemented with $0.5 \mathrm{mg} / \mathrm{l} \mathrm{BA}$, $0.5 \mathrm{mg} / \mathrm{G} \mathrm{GA}_{3}$ and $0.1 \mathrm{mg} / \mathrm{l} \mathrm{IBA}$

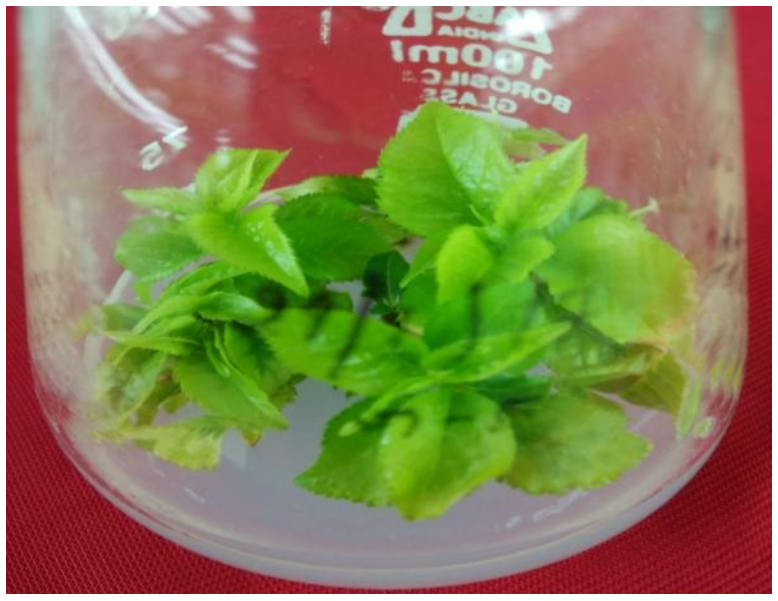

Fig.2 Roots development in Gisela 5 in full strength MS medium fortified with $0.5 \mathrm{mg} / \mathrm{l}$ IBA (a) and in vitro rooted plantlets (b)
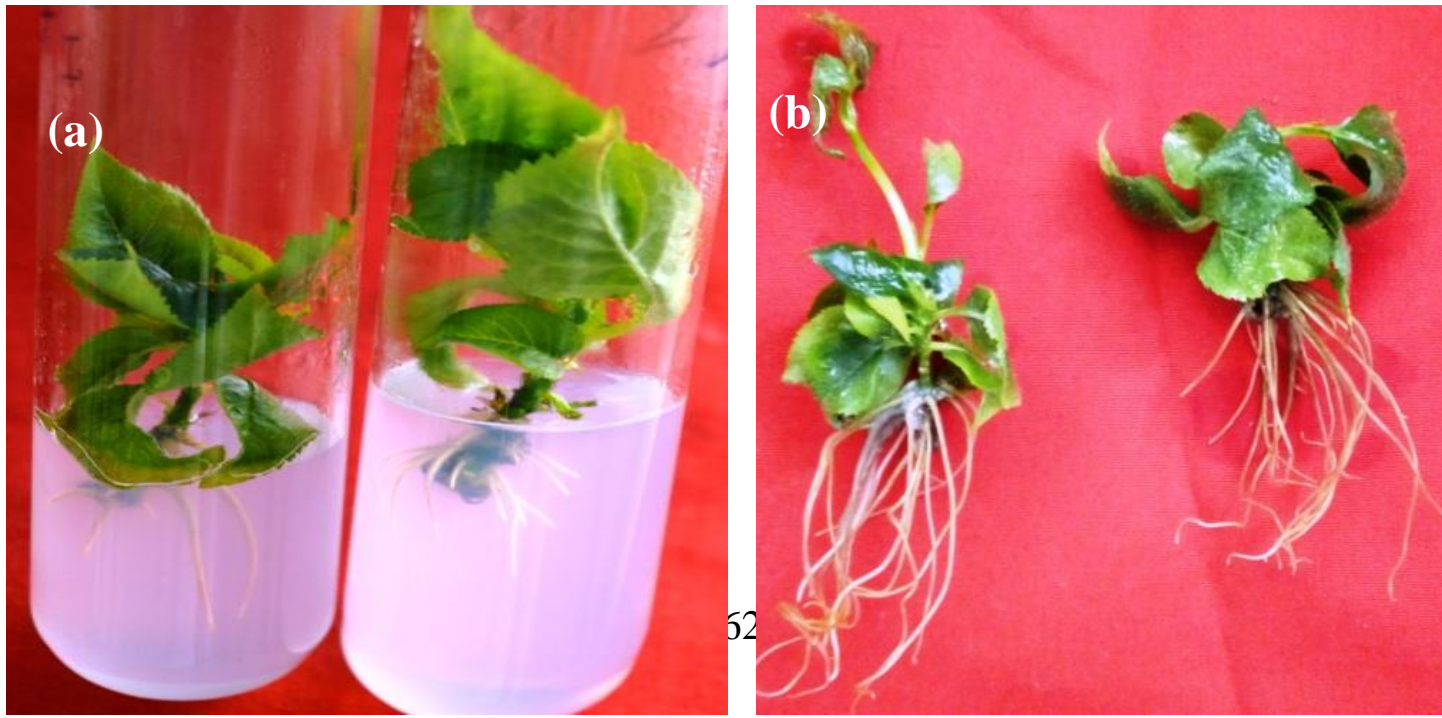
Fig.3 Roots development in Gisela 5 in half strength MS medium fortified with $1.5 \mathrm{mg} / \mathrm{l}$ IBA (a) and in vitro rooted plantlets (b)
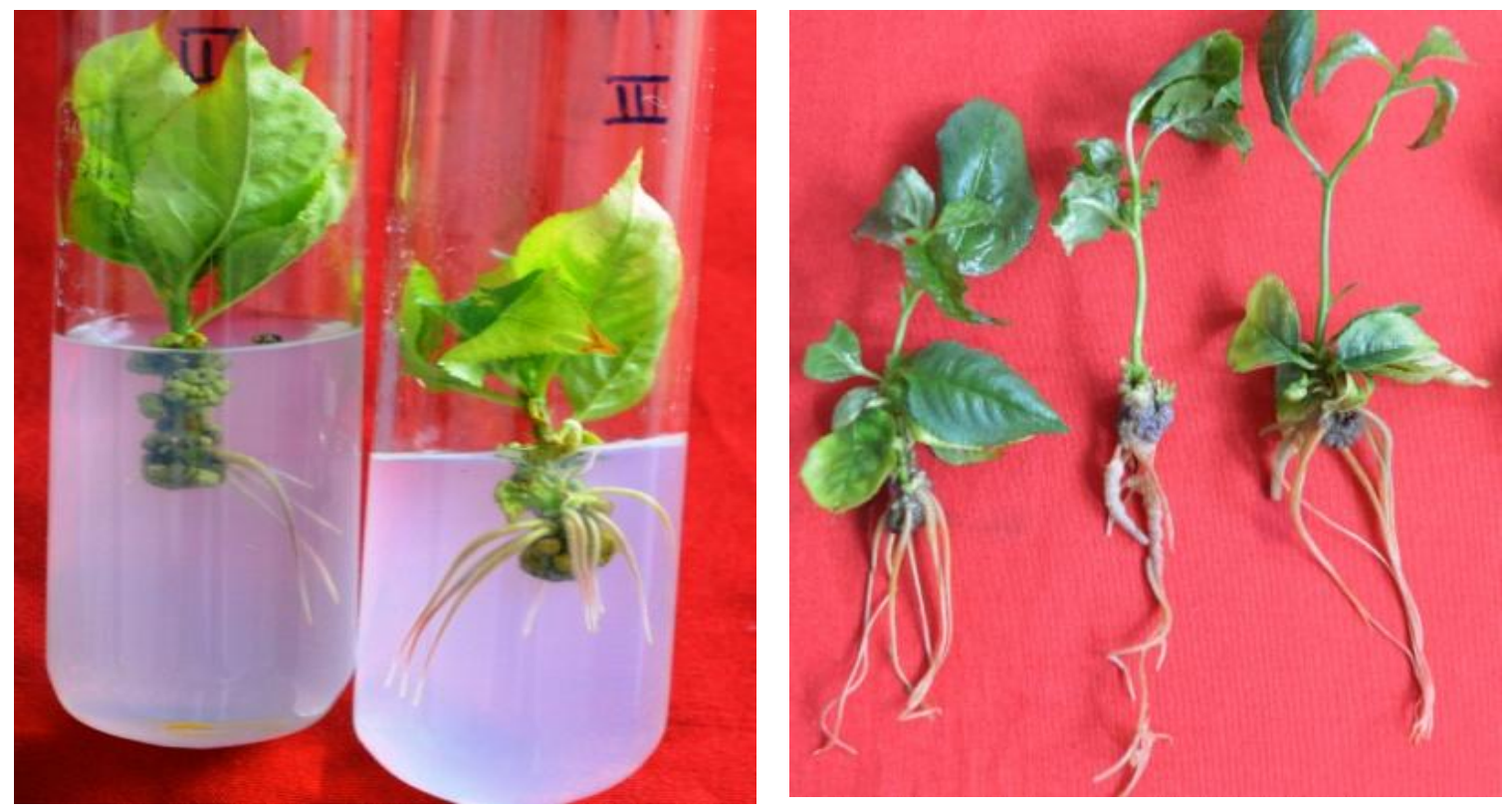

Fig.4 Completely hardened plants of Gisela 5 after 4 weeks of transfer

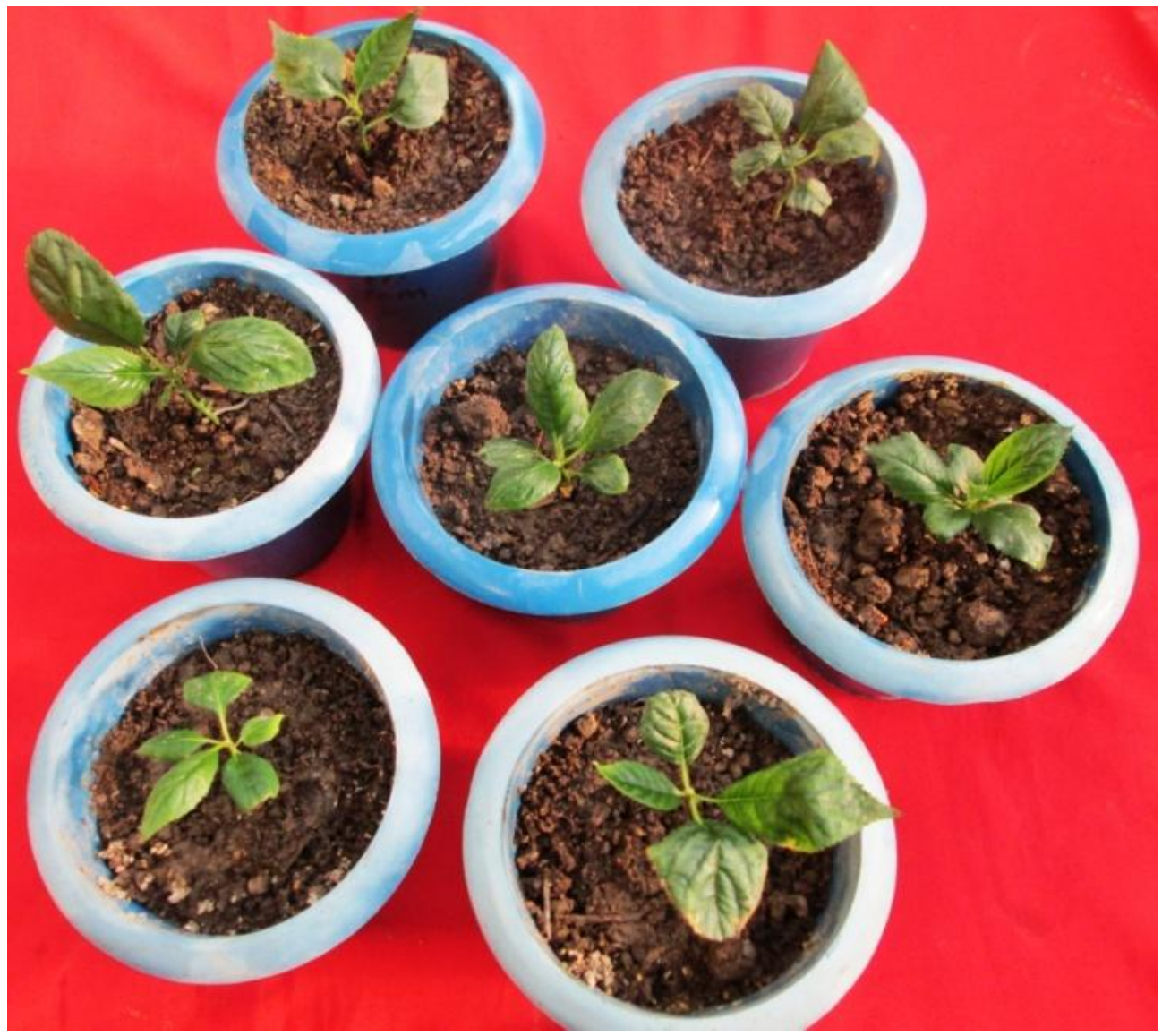


Table.1 Effect of different concentration and combination of plant growth regulators on in vitro establishment of Gisela 5 explants

\begin{tabular}{|c|c|c|c|c|c|}
\hline \multicolumn{4}{|c|}{$\begin{array}{c}\text { Nutrient Medium } \\
\text { MS basal fortified with GR (mg/l) }\end{array}$} & \multirow{2}{*}{$\begin{array}{c}\text { Days taken } \\
\text { for bud } \\
\text { burst }\end{array}$} & \multirow[t]{2}{*}{$\begin{array}{l}\text { Per cent bud } \\
\text { proliferation }\end{array}$} \\
\hline BA & Kin & TDZ & $\mathbf{G A}_{3}$ & & \\
\hline 0.5 & - & - & 0.5 & $12-14$ & $75.00(59.76)$ \\
\hline 0.5 & - & - & 1.0 & $13-16$ & $49.07(45.96)$ \\
\hline 1.0 & - & - & 0.5 & $12-18$ & $67.14(56.43)$ \\
\hline 1.0 & - & - & 1.0 & $14-18$ & $59.00(50.00)$ \\
\hline- & 0.5 & - & 0.5 & $15-21$ & $39.13(37.25)$ \\
\hline- & 1.0 & - & 0.5 & $16-19$ & $31.50(34.81)$ \\
\hline- & 0.5 & - & 1.0 & $20-25$ & $21.75(28.26)$ \\
\hline- & 1.0 & - & 1.0 & $18-23$ & $18.71(26.10)$ \\
\hline- & - & 0.5 & 0.5 & $18-21$ & $11.87(20.04)$ \\
\hline- & - & 0.5 & 1.0 & $20-21$ & $9.16(17.25)$ \\
\hline- & - & 1.0 & 0.5 & $17-18$ & $0.00(0.00)$ \\
\hline- & - & 1.0 & 1.0 & $20-21$ & $0.00(0.00)$ \\
\hline $\mathrm{CD}_{0.05}$ & & & & & $1.15(0.83)$ \\
\hline $\mathrm{SE} \pm$ & & & & & $0.37(0.27)$ \\
\hline
\end{tabular}

Values in parenthesis are arc sine transformed values.

$\mathrm{CD}=$ Critical difference; $\mathrm{SE}=$ Standard error

Table.2 Effect of different concentration and combination of plant growth regulators on in vitro shoot multiplication of Gisela 5

\begin{tabular}{|c|c|c|c|c|c|c|}
\hline \multicolumn{5}{|c|}{$\begin{array}{c}\text { Medium Composition } \\
\text { MS (Basal medium) + GR }(\mathrm{mg} / \mathrm{l})\end{array}$} & \multirow[t]{2}{*}{ Multiplication rate } & \multirow{2}{*}{$\begin{array}{c}\text { Average } \\
\text { length of } \\
\text { shoots }(\mathrm{cm})\end{array}$} \\
\hline $\mathbf{B A}$ & TDZ & $\mathbf{G A}_{3}$ & IBA & Kin & & \\
\hline- & - & - & - & - & $1: 2$ & 1.65 \\
\hline 0.50 & - & 0.50 & - & - & $1: 3$ & 0.45 \\
\hline 1.00 & - & 1.00 & - & - & $1: 2$ & 0.75 \\
\hline 0.50 & - & - & 0.10 & - & $1: 3$ & 1.00 \\
\hline 0.50 & - & - & 0.20 & - & $1: 4$ & 1.50 \\
\hline 1.00 & - & - & 0.10 & - & $1: 1$ & 1.75 \\
\hline 1.00 & - & - & 0.20 & - & $1: 2$ & 1.68 \\
\hline- & 0.50 & 0.50 & - & - & $1: 4$ & 0.25 \\
\hline- & 0.50 & 0.30 & - & - & $1: 5$ & 0.75 \\
\hline- & 1.00 & 1.00 & - & - & $1: 5$ & 0.35 \\
\hline- & 0.50 & - & 0.10 & - & $1: 3$ & 0.75 \\
\hline- & 1.00 & - & 0.20 & - & $1: 2$ & 1.25 \\
\hline 0.30 & - & 0.20 & - & - & $1: 5$ & 1.75 \\
\hline 0.50 & - & 0.50 & 0.10 & - & $1: 6$ & 2.50 \\
\hline 0.30 & - & 0.20 & 0.10 & - & $1: 5$ & 1.65 \\
\hline- & 0.50 & 0.30 & 0.10 & - & $1: 3$ & 1.25 \\
\hline 0.50 & - & 0.30 & 0.10 & - & $1: 1$ & 1.35 \\
\hline 0.50 & - & 0.30 & - & - & $1: 2$ & 0.25 \\
\hline 0.50 & - & 0.20 & - & - & $1: 4$ & 1.00 \\
\hline 0.25 & - & - & 0.10 & 0.25 & $1: 5$ & 1.50 \\
\hline 0.50 & - & - & 0.10 & 0.50 & $1: 3$ & 1.75 \\
\hline 0.30 & - & 0.50 & 0.10 & - & $1: 5$ & 2.75 \\
\hline
\end{tabular}


Table.3 Effect of subculturing on shoot multiplication and per cent rooting in Gisela 5

\begin{tabular}{|c|c|c|c|c|}
\hline Passage & $\begin{array}{c}\text { Rate of } \\
\text { multiplication }\end{array}$ & $\begin{array}{c}\text { Shoot length } \\
(\mathbf{c m})\end{array}$ & $\begin{array}{c}\text { Average no. } \\
\text { of leaves }\end{array}$ & Per cent rooting \\
\hline Establishment & $1: 1$ & 3 & 3 & - \\
\hline $\mathrm{I}^{\mathrm{st}}$ subculturing & $1: 5$ & 3.5 & 6 & No rooting \\
\hline $\mathrm{II}^{\mathrm{nd}}$ subculturing & $1: 6$ & 4.5 & 10 & $10 \%$ rooting \\
\hline $\mathrm{III}^{\mathrm{rd}}$ subculturing & $1: 9$ & 5.5 & 13 & $35 \%$ rooting \\
\hline $\mathrm{IV}^{\mathrm{th}}$ subculturing & $1: 10$ & 6.5 & 15 & $65 \%$ rooting \\
\hline
\end{tabular}

Table.4 In vitro rooting of Gisela 5 on different concentrations of IBA in full strength and half strength semisolid MS medium

\begin{tabular}{|c|c|c|c|c|c|c|}
\hline Strength & $\begin{array}{c}\text { Concentration } \\
(\mathrm{mg} / \mathrm{l})\end{array}$ & $\begin{array}{c}\text { Days taken } \\
\text { for root } \\
\text { initiation }\end{array}$ & $\begin{array}{c}\text { Days } \\
\text { taken } \\
\text { for full } \\
\text { rooting }\end{array}$ & $\begin{array}{l}\text { Per cent } \\
\text { rooting }\end{array}$ & $\begin{array}{c}\text { Root } \\
\text { length } \\
(\mathrm{cm})\end{array}$ & $\begin{array}{c}\text { No. of } \\
\text { roots per } \\
\text { shoot }\end{array}$ \\
\hline \multirow{4}{*}{$\begin{array}{c}\text { Full } \\
\text { strength }\end{array}$} & 0.5 & 13 & 38 & $100.00(90.00)$ & 6 & 4 \\
\hline & 1.0 & 20 & 37 & $50.00(44.98)$ & 4 & 3 \\
\hline & 1.5 & 20 & 37 & $40.11(39.28)$ & 5 & 4 \\
\hline & 2.0 & 14 & 37 & $10.00(18.42)$ & 4 & 3 \\
\hline \multirow{4}{*}{$\begin{array}{c}\text { Half } \\
\text { strength }\end{array}$} & 0.5 & 20 & 38 & $30.00(33.19)$ & 5 & 3 \\
\hline & 1.0 & 22 & 36 & $10.08(18.50)$ & 4 & 4 \\
\hline & 1.5 & 22 & 36 & $50.01(44.99)$ & 5 & 3 \\
\hline & 2.0 & 21 & 38 & $20.00(26.55)$ & 5 & 2 \\
\hline $\mathrm{CD}_{0.05}$ & \multicolumn{6}{|c|}{0.53} \\
\hline $\mathrm{SE} \pm$ & \multicolumn{6}{|c|}{0.17} \\
\hline
\end{tabular}

Values in parenthesis are arc sine transformed values.

$\mathrm{CD}=$ Critical difference; $\mathrm{SE}=$ Standard error

\section{In vitro rooting}

The present investigation showed that maximum in vitro rooting (100\%) was achieved on full strength solid MS medium fortified with $0.5 \mathrm{mg} / \mathrm{l}$ IBA (Table 4 and Figure 2a), whereas, very less rooting was achieved on full strength solid MS medium fortified with IAA and NAA. The highest root number and length was observed on full strength solid MS medium supplemented with $0.5 \mathrm{mg} / \mathrm{l}$ IBA followed by $1.0 \mathrm{mg} / \mathrm{l} \mathrm{NAA}$ and $0.5 \mathrm{mg} / \mathrm{l}$ IAA without any callus at the cut end. In half strength solid MS medium fortified with $1.5 \mathrm{mg} / \mathrm{l} \mathrm{IBA}$, maximum rooting was achieved (Table 4 and Figure $3 a$ ) as compared to NAA and IAA supplemented medium. Low concentration of sucrose $(15 \mathrm{~g} / \mathrm{l})$ did not inhibit root formation in any of the auxin concentration tried.
These results are similar to the findings of Sisko (2011) and Clapa et al., (2013) who obtained maximum rooting percentage on both full strength and half strength MS medium fortified with different concentrations of auxins in cherry rootstocks.

\section{Hardening and acclimatization}

After 3 weeks, the rooted plantlets obtained were removed from agar gelled medium (Figure $2 \mathrm{~b}$ and $3 \mathrm{~b}$ ) and transplanted in sterilized sand for hardening. The plants were kept in the glasshouse and 90 per cent survival was obtained after 4 weeks of transfer (Figure 4). It was observed that better root and shoot development prior to hardening determined the survival of in vitro raised plants which is also supported by Minaev et al., (2003) and Vujovic et al., (2012). 


\section{Acknowledgements}

We are thankful to PCDO Bajaura, kullu, Himachal Pradesh, India for providing us material for establishment of in vitro cultures of Gisela 5.

\section{References}

Beura, S., Singh, R. and Jagadev, P. N. 2003. In vitro multiplication studies in gladiolus $\mathrm{cv}$. American Beauty. Orissa. J. Hort. 31, 101105.

Buyukdemirci, H. 2008. The effects of medium ingredients on shoot propagation and rooting of cherry rootstocks in vitro. Acta. Hort. 795: 419-422.

Clapa, D., Fira, A., Simu, M. and Horga, V. C. 2013. In vitro propagation of Gisela 5 cherry rootstock. Fruit. Grow. Res. 29: 100105.

Dimassi-Theriou, K. 1995. In vitro rooting of rootstock 'GF677' (Prunus amygdalus $\times P$. persica) as influenced by mineral concentration of the nutrient medium and type of culture-tube sealing material. J. Hort. Sci. 70: 105-108.

Fachinello, J. C. 2000. Problemáticas das mudas de plantas frutíferas de caroço. Paper presented at 1 st Simpósio Internacional de Frutas de Caroço- Pêssegos, Nectarinas e Ameixas, 17-18 October, Porto. Alegre, UFRGS, pp. 25-40.

Filiz, G., Fatma, K., and Bekir, S. 2010. The in vitro micropropagation of some clonal cherry rootstocks. Jou. Nat. \& Appl. Sci. 14 (2): p144.

Gomez, KA. And Gomez, AA. 1984. Statistical Procedures for Agricultural Research. (John Wiley and Sons, New York).

Grant, N. J. and Hammatt, N. 1999. Increased root and shoot production during micropropagation of cherry and apple rootstocks: effect of subculture frequency.
Tree physiol. 19: 899-903.

Holtz, B., Ferguson, L. and Allen, G. E. 1995. Pistachio production, rootstocks production and budding. Cooperative extension, University of California, Oakland, CA, USA, pp. 54-56.

Marjanovic, D., Mededovic, S., Causevic, A. and Hadziselimovic, R. 2000. Micropropagation of wild cherry (Prunus avium L.) in vitro. Radovi Šmarskog Fakulteta Univerziteta u Sarajevu. 30(1): 35-42.

Minaev, V. A.., Verzilin, A. V. and Vysostskii, V. A. 2003. Clonal micropropagation of low vigour clonal apple rootstocks bred at the Michurinsk State Agricultural University. Sadov-i-Vinog. 5: 12-13.

Muna, A. S., Ahmad, A. K., Mahmoud, K. and Rahman K. A. 1999. In vitro propagation of a semi-dwarfing cherry rootstock. Plant. Cel. Tiss. Org. Cul. 59: 203-208.

Murashige, T., Skoog, F. 1962. A revised medium for rapid growth and bio assays with tobacco tissue cultures. Physiol. Plantarum. 15: 473-497.

Nordstrom, A. C. and Eliasson, L. 1986. Uptake and translocation of C14-labled benzylaminopurine in apple shoots grown in vitro in relation to shoot development. Physiol. Plantar. 68(3): 431-435.

Sisko, M. 2011. In vitro propagation of Gisela 5 (Prunus cerasus $\times P$. canescens). Agricultura. 8: 31-34.

Thakur, M., Sharma, V., Sharma, D. P., Kumari, G. and Vivek, M. 2016. In Vitro Propagation of Virus Indexed Gisela-5 (Prunus cerasus $\mathrm{x}$ Prunus canescens) - Clonal Cherry Rootstock. Inter. Jour. Crop. Sci. Tech. 2(2): 87-99.

Vujovic, T., Ruzi, D. and Cerovi, R. 2012. In vitro shoot multiplication as influenced by repeated subculturing of shoots of contemporary fruit rootstocks. Hort. Sci. (Prague). 39(3): 101-107.

\section{How to cite this article:}

Vishal Sharma, Manisha Thakur and Akhil Kumar. 2017. An Efficient Method for In Vitro Propagation of Gisela 5 (Prunus Cerasus X Prunus Canescens) - Clonal Cherry Rootstock. Int.J.Curr.Microbiol.App.Sci. 6(8): 2617-2624. doi: https://doi.org/10.20546/ijcmas.2017.608.311 